\title{
EFFECT OF HEAT TREATMENT ON CHARPY IMPACT ENERGY OF MICROALLOYED STEEL
}

\author{
Gorazd Kosec, Jelena Vojvodič Tuma, Mirko Gojić, Aleš Nagode, Antun Stoić, Ivan Samardžić, Borut Kosec
}

Original scientific paper In this paper the microalloyed high-strength low-alloy (HSLA) Niomol 490K steel with an addition of niobium $(0,032$ wt. \%) has been investigated. Heat treatment of the steel consisted of austenitisation at $1250^{\circ} \mathrm{C}$ for 3 minutes and reheating up to $750{ }^{\circ} \mathrm{C}$ for $5 \mathrm{~s}$. After austenitization the quenching was carried out in water with temperature of $70{ }^{\circ} \mathrm{C}$ and then in a lead bath up to $400{ }^{\circ} \mathrm{C}$ following cooling on the air. It was found that Charpy impact energy is higher and the transition temperature is lower for the transformation of austenite to bainite than to martensite microstructure. Experimental results showed that different fracture surface was observed. It is shown that preferred cleavage fracture occurred in the lattice plane (001) independently of steel microstructure.

Keywords: Charpy impact energy, Fracture surface, HSLA steel, Microstructure, Transition temperature

Utjecaj toplinske obrade na Charpy energiju udara mikrolegiranog čelika

Izvorni znanstveni rad U ovom radu istraživan je niskolegirani visokočvrsti čelik Niomol 490K koji sadrži dodatak niobija (0,032 mas. \%). Toplinska obrada čelika se sastojala od austenitizacije pri $1250{ }^{\circ} \mathrm{C}$ u trajanju od 5 minuta i ponovnog zagrijavanja do $750{ }^{\circ} \mathrm{C}$ u trajanju od $5 \mathrm{~s}$. Nakon austenitizacije provedeno je kaljenje u vodi kod temperature od $70{ }^{\circ} \mathrm{C}$ i u olovnoj kupci do temperature od $400{ }^{\circ} \mathrm{C}$ uz naknadno hlađenje na zraku. Utvrđeno je da je Charpy energija udara viša, a prijelazna temperatura niža za transformaciju austenita u bainit nego kod transformacije austenita u martenzitnu mikrostrukturu. Eksperimentalni rezultati su pokazali različite prijelomne površine. Pokazano je da je preferentno cijepajući prijelom zapažen po ravnini rešetke (001), neovisno o mikrostrukturi.

Ključne riječi: Charpy energija udara, Prijelomna površina, HSLA čelik, Mikrostruktura, Prijelazna temperatura

\section{Introduction}

High strength low alloy (HSLA) steels represent a group of low carbon steels that utilise small amounts of alloying elements, such as $\mathrm{Mo}, \mathrm{Ti}, \mathrm{V}$ and $\mathrm{Nb}$, to attain high yield strengths in the as rolled condition $[1 \div 3]$. The main properties of HSLA steels are: high strength and toughness, corrosion resistance, weldability and cost effectiveness [4, 5]. They are used for different applications (pipelines, offshore platforms, ship buildings, reservoirs for liquid natural gas etc.). HSLA steels are used for petrochemical vessels because of their excellent weldability and resistance to hydrogen embrittlement. It is known that the toughness and transition temperature are very important for these steels and because of that Charpy impact energy is highly dependent on the microstructure $[6,7]$

In the previously published study it was found that the toughness transition temperature of welded plates with thickness 15 was by about $20{ }^{\circ} \mathrm{C}$ higher than for $25 \mathrm{~mm}$ plates [8]. This finding confirmed simulation results with different $800{ }^{\circ} \mathrm{C}$ to $500{ }^{\circ} \mathrm{C}$ cooling rate [9]. In the scientific literature this problem has not been described yet. It is well known that microstructures of the base metal, heat affected zone (HAZ) and weld metal are different [10]. It is the result of effect of heat flow and the cooling rate of steel during welding process. For example, in this case of multilayer welding the deposition of each layer includes heating of underlaying microstructure [11]. Difference in transition temperature of HAZ of weldments of structural steels is explained with the effect of local brittle zones (LBZ) [12, 13]. It was suggested that the ability of Charpy tests to detect brittle zones was questionable [14] and that for the same steel the welding procedure should be adjusted to the thickness of the welded plate. LBZ-s cause instable local fracture behaviour of the steel in HAZ [15]. In highly constrained geometries, the local toughness dominates the failure process and deviates the crack into harder and more brittle weld metal, while in low constraint configurations, the size of the plastic zone promotes crack deviation into the softer and tougher parent plate [16]. By testing of simulated welds a linear relation between the inverse square root of the fracture facets size and the impact transition temperature was found [17]. LBZ were found also in HAZ of welds of the cryogenic $9 \% \mathrm{Ni}$ steel [18].

It is concluded from the survey of references that the harmful effect of LBZ on toughness is well established, nevertheless, no experimentally verified explanation of the propensity of different microstructure to form LBZ in the HAZ of welds was proposed, so far. Based on the field of experience and investigation [19], it was assumed that the formation of LBZ is related to changes in particular constituents of HAZ microstructure. The aim of this investigation was to verify the effect of short reheat at a temperature of partial transformation on notch properties of martensite and lower bainite microstructure [20].

\section{Experimental work}

All experimental work was performed on the HSLA Niomol $490 \mathrm{~K}$ steel produced by electric furnace in industrial conditions. The chemical composition of the investigated steel is shown in Tab. 1.

As can be seen from Tab. 1 the steel is microalloyed with niobium in order to accelerate the formation of ferrite and due to grain refinement [21, 22]. The steel slabs were hot rolled into plate $15 \mathrm{~mm}$ thickness. Samples cut from $15 \mathrm{~mm}$ plate were austenitised at $1250{ }^{\circ} \mathrm{C}$ with holding time of 3 minutes. The first group of 
Table 1 Chemical composition od steel investigated, wt. \%

\begin{tabular}{|c|c|c|c|c|c|c|c|c|c|c|c|}
\hline $\mathrm{C}$ & $\mathrm{S}$ & $\mathrm{Al}$ & $\mathrm{Ni}$ & $\mathrm{Cr}$ & $\mathrm{Si}$ & $\mathrm{Mn}$ & $\mathrm{P}$ & $\mathrm{Cu}$ & $\mathrm{Mo}$ & $\mathrm{Ti}$ & $\mathrm{Nb}$ \\
\hline 0,11 & 0,004 & 0,019 & 0,15 & 0,54 & 0,36 & 0,50 & 0,012 & 0,29 & 0,34 & 0,014 & 0,032 \\
\hline
\end{tabular}

samples was quenched in water. The second group of samples was quenched up to $400{ }^{\circ} \mathrm{C}$ in lead bath for 5 minutes and then cooled in the air. After that the samples are reheated for $5 \mathrm{~s}$ up to $750{ }^{\circ} \mathrm{C}$ (with holding time of 3 s) with direct conduction heating and air cooled with the cooling time $\mathrm{t}_{750 \div 500^{\circ} \mathrm{C}}=17 \mathrm{~s}$ using Gleeble 1500 device. By this heat treatment of the steel the welding process at next deposition was simulated by means of short time annealing $(5 \mathrm{~s})$ in intercritical temperature range $\left(750{ }^{\circ} \mathrm{C}\right)$ where two-phase region (austenite and ferrite) exists. On all specimens the Charpy V-notch was cut after heat treatment.

The Charpy tests were carried out in temperature range from $196{ }^{\circ} \mathrm{C}$ to $60{ }^{\circ} \mathrm{C}$. Hardness was measured by Vickers method (HV5). Samples for metallographic analysis were prepared by mechanically grinding and polishing. Etching of samples was performed by nital solution. Metallography analysis was performed using scanning electron microscopy (SEM) method. Fractography analysis was carried on Charpy samples fractured. The fracture surfaces were investigated with SEM Jeol JSM 5610 [23, 24], and the space orientation of cleavage facets was determined with electron backscatter diffraction (EBSD) method [25].

\section{Results and discussion}

Representative scanning electron micrographs of the Niomol $490 \mathrm{~K}$ steel in different states are presented in Figs. $1 \div 3$. The microstructure of the as delivered steel consisted of acicular ferrite and degenerated pearlite (Fig. 1a).
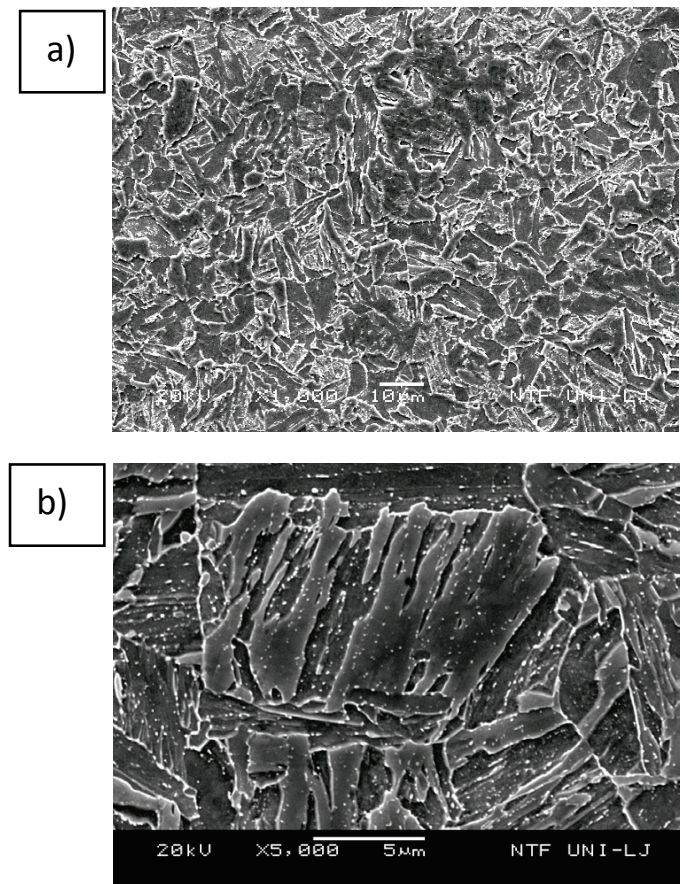

Figure 1 Microstructure of the steel in delivered state (a), and after reheating at $750{ }^{\circ} \mathrm{C}(\mathrm{b})$
This pearlite can be formed by nucleation of cementite at austenite/ferrite boundaries followed by carbide-free ferrite layers enclosing the cementite in the temperature range the formation of conventional lamellar pearlite and upper bainite [26]. After rapid heating up to $750{ }^{\circ} \mathrm{C}$ microstructure consisted of accicular ferrite, degenerated pearlite and secondary martensite (Fig. 1b). The quenching in water from $1250{ }^{\circ} \mathrm{C}$ produced a coarse microstructure with platelets of ferrite and lath of primary martensite (Fig. 2a). After rapid heating of quenched samples up to $750{ }^{\circ} \mathrm{C}$ primary and secondary martensite occurred (Fig. 2b). In Fig 2b stringers of cementite particles in ferrite grains and inserts of secondary martensite at grain boundaries can be also observed. The cooling in lead bath from $1250{ }^{\circ} \mathrm{C}$ up to $400{ }^{\circ} \mathrm{C}$ produced the coarse grain of bainite microstructure that consisted of stringers of cementite particles at borders of ferrite platelets, (Fig. 3a). After reheat (up to $750{ }^{\circ} \mathrm{C}$ ) lower bainite which was obtained with cooling in lead bath from $1250{ }^{\circ} \mathrm{C}$ changed into a microstructure consisting of platelets of secondary martensite at the boundaries of coarse grains and bainite microstructure (Fig. 3b).
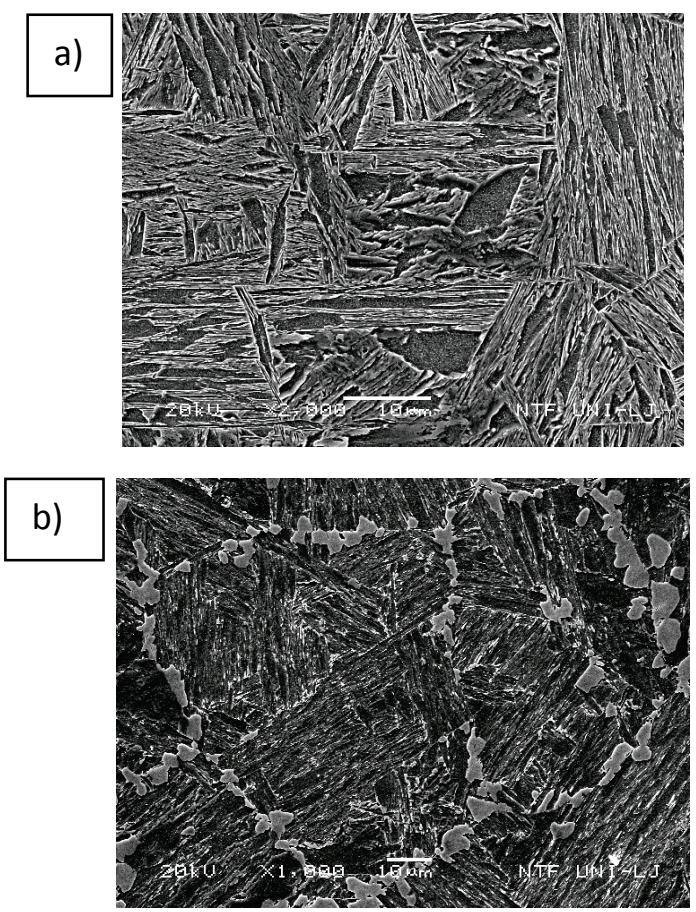

Figure 2 SEM micrographs of the steel after water quenching from $1250{ }^{\circ} \mathrm{C}$ (a) and after reheating (b)

The hardness values of the different microstructures are listed in Tab. 2. The low hardness of the as delivered steel increased significantly after reheat (248 HV5). After water quenching from $1250{ }^{\circ} \mathrm{C}$ the hardness was much higher in comparison to the initial hardness (hardness of the as delivered steel). After water quenching from 1250 ${ }^{\circ} \mathrm{C}$, the greatest hardness was obtained (383 HV5) that decreased significantly at reheat, still, it remained high. After quenching in lead bath from $1250{ }^{\circ} \mathrm{C}$ the hardness was increased moderately (257 HV5) and it was higher after reheat. The experimental findings on microstructure 
(Figs. $1 \div 3$ ) and hardness (Tab. 2) indicate that depending on the initial microstructure three different processes may occur at short reheat: (1) the dissolution of cementite with a formation of secondary austenite around cementite particles in the interior of ferrite grains and its transformation to secondary martensite at cooling, (2) the formation of inserts (grains) of secondary martensite at triple points and boundaries of ferrite grains and (3) the decomposition of primary martensite.
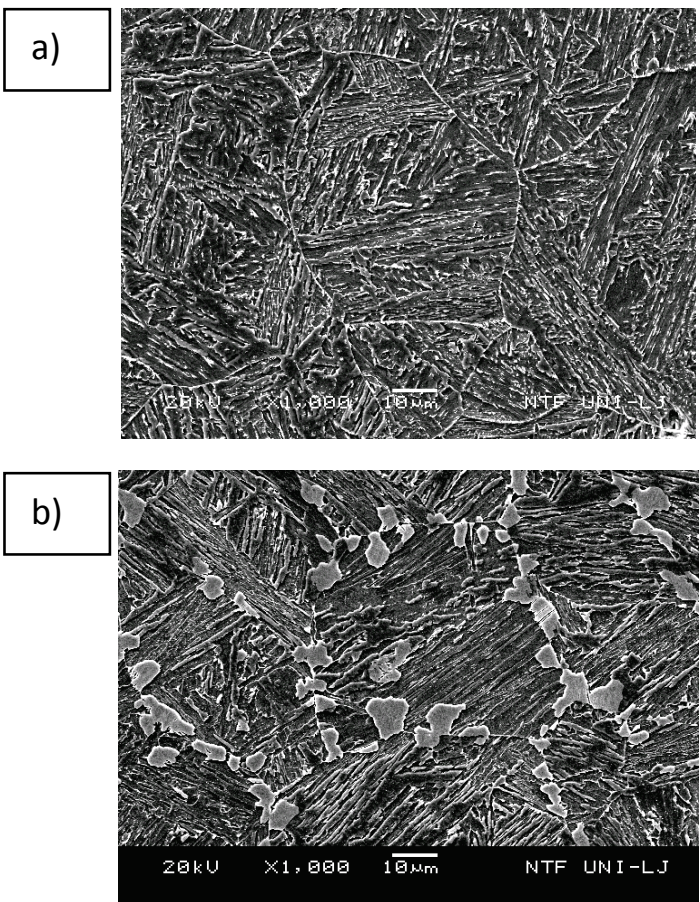

Figure 3 SEM micrographs of the steel after lead bath cooling from $1250{ }^{\circ} \mathrm{C}(\mathrm{a})$ and after reheating (b)

Table 2 Hardness of steel after different thermal treatment

\begin{tabular}{|l|c|}
\hline \multicolumn{1}{|c|}{ Thermal treatment } & Hardness, HV 5 \\
\hline As delivered & 205 \\
\hline As delivered $+750{ }^{\circ} \mathrm{C}$ & 248 \\
\hline $1250^{\circ} \mathrm{C} /$ water & 383 \\
\hline $1250^{\circ} \mathrm{C} /$ water $+750{ }^{\circ} \mathrm{C}$ & 320 \\
\hline $1250^{\circ} \mathrm{C} /$ lead bath at $400^{\circ} \mathrm{C}$ & 257 \\
\hline $1250^{\circ} \mathrm{C} /$ lead bath at $400^{\circ} \mathrm{C}+750^{\circ} \mathrm{C}$ & 298 \\
\hline
\end{tabular}

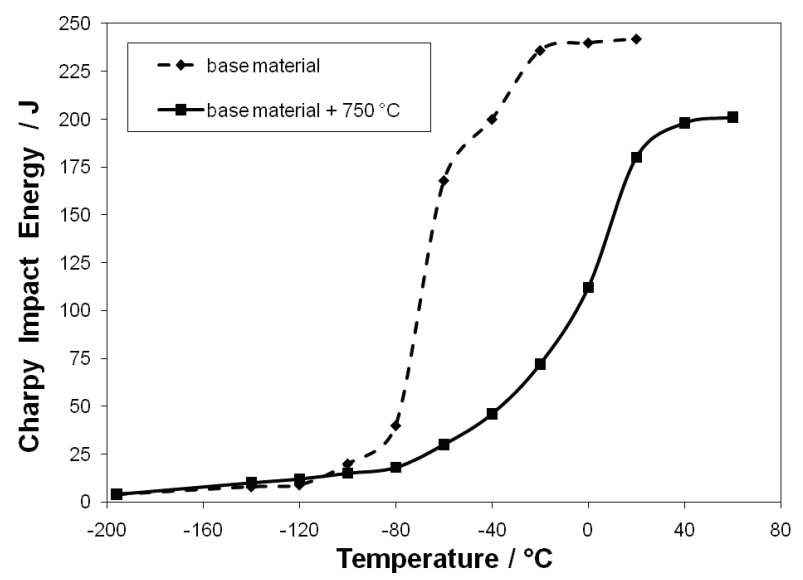

Figure 4 Charpy impact energy versus testing temperature for the delivered, and reheated steel up to $750{ }^{\circ} \mathrm{C}$

The correlation between Charpy impact energy and test temperature of the steel in both delivered state and after heat treatment is presented in Figs. $4 \div 6$. It can be seen that Charpy impact energy is closely associated with the microstructure. The Charpy curves show that at upper shelf range the microstructure behaves as $100 \%$ ductile fracture, while at lower shelf the Charpy impact energy tends to minimum (brittle fracture). The transition temperature can be expressed in different ways. One of them is that the Charpy impact transition temperature can be estimated as the average of maximum and minimum shelf energy values in Charpy curves [27]. In this investigation the trend in shift in the transition temperature was observed.

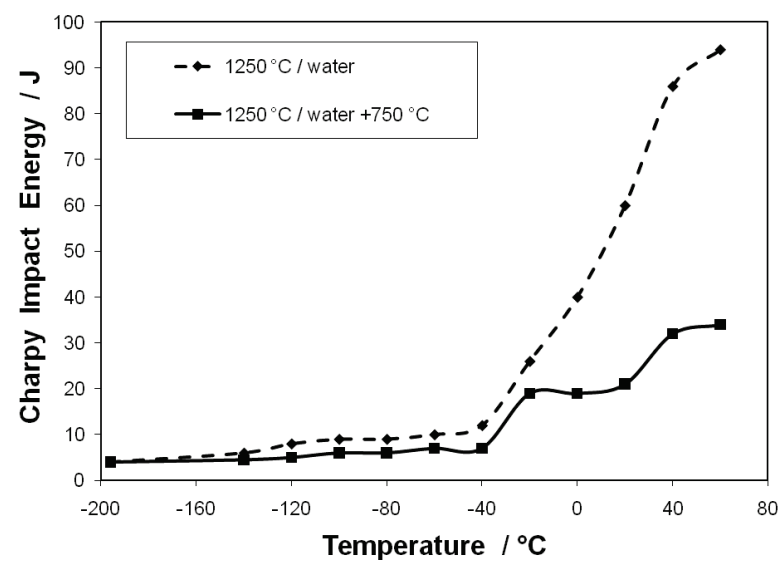

Figure 5 Charpy impact energy versus testing temperature for the steel quenched in water from $1250{ }^{\circ} \mathrm{C}$, and after reheating up to $750{ }^{\circ} \mathrm{C}$

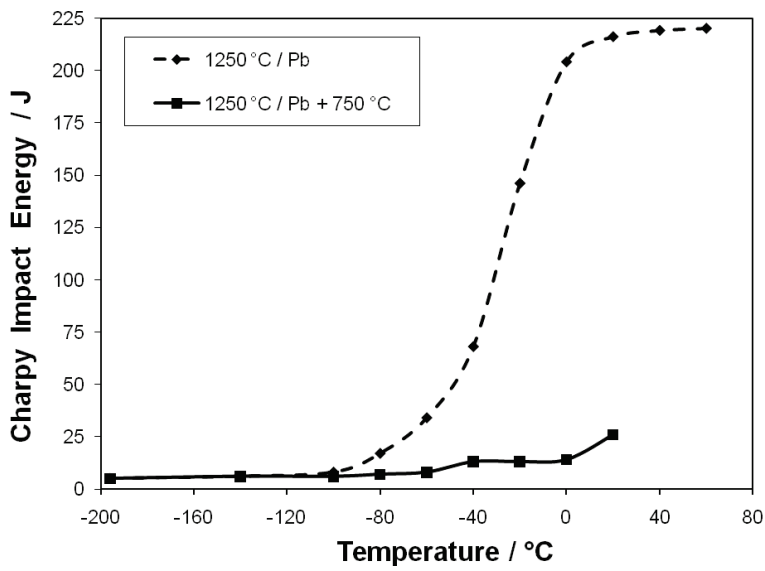

Figure 6 Charpy impact energy versus testing temperature for the steel cooled from $1250^{\circ} \mathrm{C}$ in lead bath at $400{ }^{\circ} \mathrm{C}$, and after reheating up to $750{ }^{\circ} \mathrm{C}$

The upper shelf Charpy V-notch impact energy is high (about $240 \mathrm{~J}$ ) and the Charpy transition temperature is low (about $-70{ }^{\circ} \mathrm{C}$ ) for the as delivered steel (Fig. 4). After quenching from $1250{ }^{\circ} \mathrm{C}$ Charpy imapct energy is decreased, while transition temperature is increased (Figs. 6 and 7). After reheating up to $750{ }^{\circ} \mathrm{C}$ the Charpy Vnotch impact energy is decreased little for the as delivered steel (by about $40 \mathrm{~J}$ ), more for martensite (by about $60 \mathrm{~J}$ ) and the most for fine and coarse lower bainite microstructure (by about $200 \mathrm{~J}$ ). Also after reheating the transition temperatures are increased, especially for the fine and coarse lower bainite microstructure.

The results of Charpy tests (Figs. $4 \div 6$ ) on the same steel cooled to fine and coarse martensite and lower bainite show that the fracture energy was greater and the 
transition temperature was lower for lower bainite than that for martensite. After the applied reheat (up to 750 $\left.{ }^{\circ} \mathrm{C}\right)$, the fracture energy was decreased and the transition temperature increased much more for lower bainite than for martensite. The difference reflects the change of both initial microstructures at reheating temperature and air cooling. For bainite, in areas of cementite particles in the interior of ferrite grains secondary martensite was formed at reheat, while, at reheat virtually only a partial decomposition of primary martensite occurred in the interior of grains. In the very short reheat time of some seconds, secondary austenite rich in carbon was formed with dissolution of cementite particles and then transformed to secondary martensite at cooling. The extent and form of decomposition of primary martensite in the applied reheating are not clear, yet. The extent of formation of secondary austenite with dissolution of cementite particles was sufficient to produce a volume of martensite that greatly diminished the notch toughness. Also, the change of primary martensite at reheating decreased significantly the fracture energy, however, the decrease was much lower than for bainite. An opposite effect would be expected after the completed decomposition of martensite.

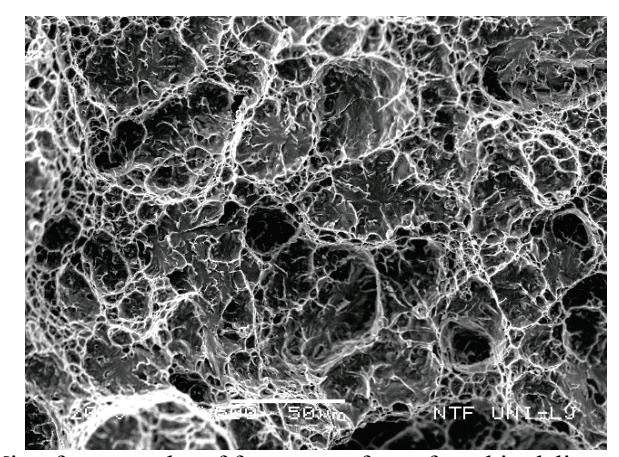

Figure 7 Microfractography of fracture surface of steel in delivered state after Charpy test at $20^{\circ} \mathrm{C}$

The fast formation of inserts of secondary martensite at grain boundaries of ferrite for the initial microstructure of martensite and lower bainite grains suggests the grain boundary carbon segregation and the piping diffusion of segregated carbon to the points of faster formation of austenite with high solubility for carbon. The effect of these inserts is not clear, nevertheless, it is possible that they are responsible for the decrease of Charpy impact energy of martensite after reheat.

It is evident that the effect of short reheating in the ferrite+austenite range is more harmful for notch toughness of lower bainite than of martensite. Therefore, it is expected that the propensity to form local brittle zones (LBZ) is greater for lower bainite than for martensite. The very different Charpy imapct energy for similar hardness suggests that the physical form of presence of carbon, in precipitates or in solid solution in martensite, affects differently notch toughness temperature than hardness.

The findings in this investigations show that for HAZ the transformation of austenite to lower bainite is more harmful for the weld quality, than the transformation to martensite, in spite of the lower hardness of bainite. Also, for notch toughness of HAZ of structural steels of similar composition that the investigated, slower cooling could be more harmful than faster cooling.

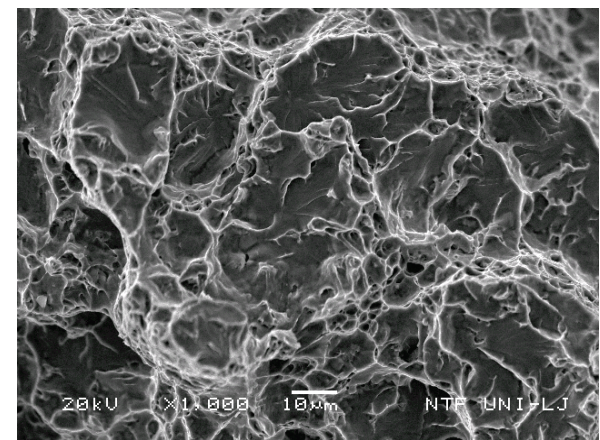

Figure 8 Microfractography of fracture surface of steel after Charpy test at $40{ }^{\circ} \mathrm{C}$

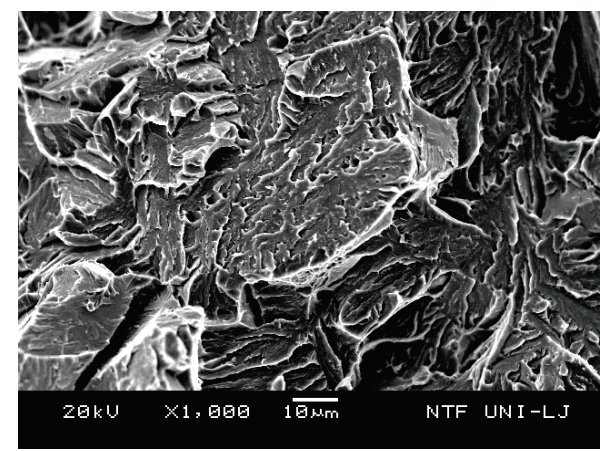

Figure 9 Microfractography of fracture surface of steel quenched from $1250{ }^{\circ} \mathrm{C}$ in water after Charpy test at $-60{ }^{\circ} \mathrm{C}$
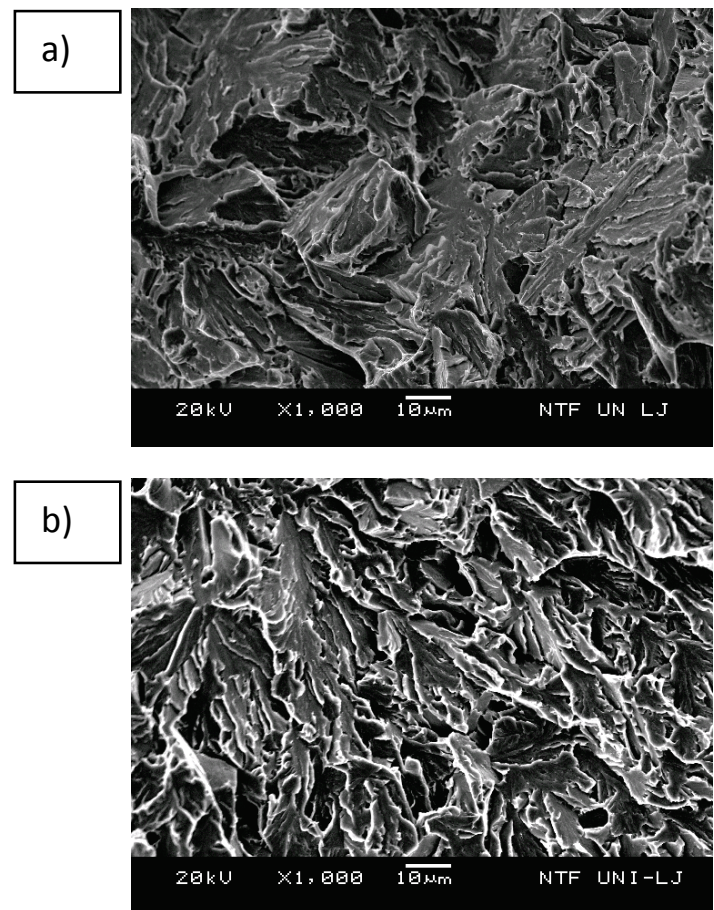

Figure 10 Microfractographs of fracture surface of steel quenched from $1250{ }^{\circ} \mathrm{C}$ in water and reheated at $750{ }^{\circ} \mathrm{C}$ (a) and cooling from $1250{ }^{\circ} \mathrm{C}$ in lead bath up to $400{ }^{\circ} \mathrm{C}$ and reheated at $750{ }^{\circ} \mathrm{C}$ (b)

Selected fractographic observations made on some broken Charpy V-notch samples are shown in Figs. $7 \div 10$. As can be seen three fracturing mechanisms were identified for the three levels of Charpy impact energy. At high Charpy impact energy the fracture surface consisted of areas of normal and of shear decohesion with dimples of different size (Fig. 7). Most of the fracturing energy in 
ductile range is consumed for the plastic deformation before the crack is started at the notch tip. Similar fracture mode is observed on microalloyed cast steel after postforging heat treatment [28]. At temperature above $-20^{\circ} \mathrm{C}$ fracture consisted of a mixture of brittle and ductile surface (Fig. 8). After quenching from $1250{ }^{\circ} \mathrm{C}$ in water the cleavage facets were coarse (Fig. 9) and without details related to the presence of inserts of secondary martensite at grain boundaries. After reheating up to 750 ${ }^{\circ} \mathrm{C}$ was observed brittle fracture by cleavage mechanism (Fig. 10). The shape and size of brittle facets was related to the size of ferrite grains. Brittle crack initiation is probably associated with carbide particles at boundaries for bainite and martensite microstructures. It is in accordance with previous fractography study [29] on Charpy V-notch impact tests which showed that microalloying elements can change the fracture mode from ductile to brittle.

The cleavage could occur in (110) and (100) lattice planes with a greater density of rivers for the (110) planes. The examinations of the obtained fractures did not confirm this observation although on cleavage facets of coarse lower bainite the rivers density was greater. The accurate EBSD (electron backscatter diffraction) analysis is achieved with the angle of approximately $70^{\circ}$ between the facet surface and the incident electron beam and a small distance between the incident spot and the electron collector. This geometry could not be achieved at the examination of the uneven fracture surfaces.

(a)

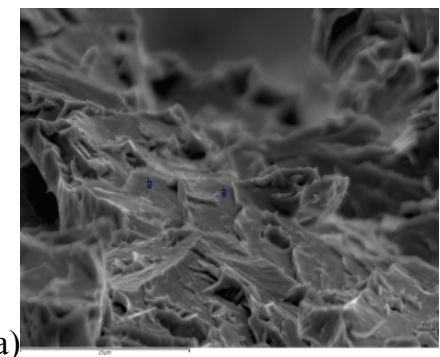

(b)

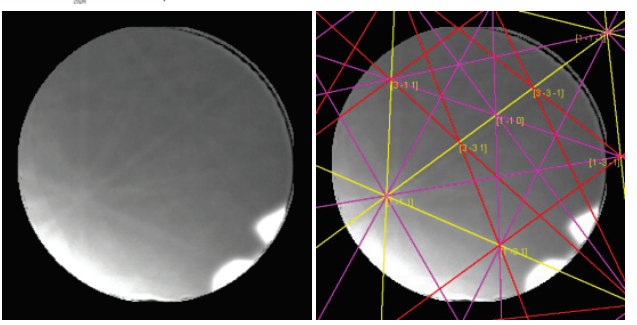

$\alpha_{\mathrm{Fe}}\{14-5-3\}\langle 419-13\rangle$

(c)

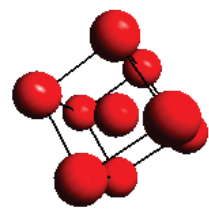

Figure 11 SEM micrography of fracture surface (a), diffraction lines (b) and lattice indexing of the cleavage facet (c) of steel cooled in lead bath from $1250{ }^{\circ} \mathrm{C}$ up to $400{ }^{\circ} \mathrm{C}$

In Figs. 11 and 12 the analysed surface, the diffraction lines and their indexes are shown for the cleavage fracture of steel cooled in lead bath from 1250 ${ }^{\circ} \mathrm{C}$ and quenched in water from $1250{ }^{\circ} \mathrm{C}$ and reheated. In the first case the cleavage surface indexing is $\{14-5-3\}$ (4 $19-13)$ and in the second $\left\{\begin{array}{lll}3 & -3 & 19\end{array}\right\}$ (13 25 6). Since the cleavage surface can have only the index corresponding to a simple lattice plane (001) or (011), it is concluded that it occurred in the lattice plane (001) independently on steel microstructure.

(a)

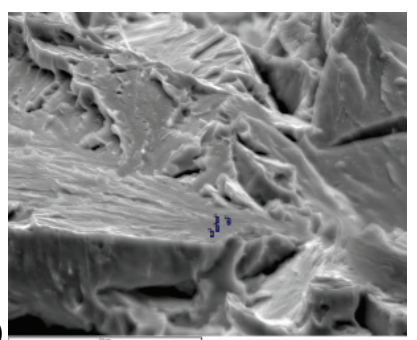

(b)

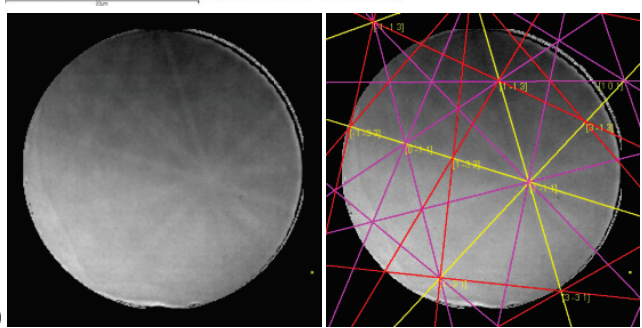

$\alpha_{\mathrm{Fe}}\left\{\begin{array}{lll}3 & -3 & 19\end{array}\langle 13256\rangle\right.$

(c)

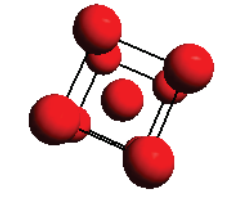

Figure12 SEM micrography of fracture surface (a), diffraction lines (b), and lattice indexing of the cleavage facet (c) of steel quenched from $1250{ }^{\circ} \mathrm{C}$ in water and reheated at $750{ }^{\circ} \mathrm{C}$

\section{Conclusions}

On the basis of experimental findings in this investigation and their analysis the following conclusions are proposed:

- the Charpy impact energy is higher and the transition temperature is lower for the transformation of austenite to bainite than to martensite microstructure;

- after short reheat at $750{ }^{\circ} \mathrm{C}$ and air cooling Charpy impact energy was decreased for approximately ten times and the transition temperature increased above $40{ }^{\circ} \mathrm{C}$ for bainite microstructure.

- particularly harmful for notch toughness and transition temperature is the transformation of austenite formed at reheat in the interior of ferrite grains with dissolution of cementite particles to secondary martensite;

- physical form of the presence of carbon in the microstructure, as precipitates or in solution in martensite, has a different effect on notch toughness than on hardness. For this reason, at similar hardness different notch toughness properties could be obtained;

- although beneficial in terms of notch toughness and transition temperature, the transformation of austenite to lower bainite in the HAZ of welds is to be avoided because of its higher propensity to form local brittle zones at short reheat in the austenite + ferrite range.

- different fracture surfaces are observed and preferred cleavage fracture occurred in the lattice plane (001) independently on steel microstructure. 


\section{Acknowledgement}

The authors want to thank professor Franc Vodopivec (Institute of Metals and Technology), professor Anton Smolej (University of Ljubljana), and professor Ladislav Kosec (University of Ljubljana) for mentorship at study of HSLA steels, Mrs. Nika Breskvar (University of Ljubljana) for SEM analysis and Mr. Boris Arzenšek (Institute of Metals and Technology) for mechanical testing.

\section{References}

[1] Vervynckt, S.; Verbeken, K.; Lopez, B.; Jones, J. J. Modern HSLA steels and role of non-recrystallisation temperature. // International Materials Science, 57 (2012), pp. 187-207. DOI: 10.1179/1743280411y.0000000013

[2] Mousavi Anijdan, S. H.; Yue, S.; Effect of ferrite deformation temperature on the mechanical properties of microalloyed steels. // Materials Science and Engineering. A 535 (2012), pp. 84-91. DOI: 10.1016/j.msea.2011.12.045

[3] Tang, S.; Lin, Z. Y.; Wang, G. D.; Misra, R. D. K. Microstructural evolution and mechanical properties of high strength microalloyed steels: Ultra Fast Cooling (UFC) versus Accelerated Cooling (ACC). // Materials Science and Engineering. A 580 (2013), pp. 257-265. DOI: 10.1016/j.msea.2013.05.016

[4] Olasolo, M.; Uranga, P.; Rodriguez-Ibabe, J. M.; López, B. Effect of austenite microstructure and cooling rate on transformation characteristics in a low carbon $\mathrm{Nb}-\mathrm{V}$ microalloyed steel. // Materials Science and Engineering. A 528 (2011), pp. 2559-2569. DOI: 10.1016/j.msea.2010.11.078

[5] Shukla, R.; Ghosh, S. G.; Chakrabarti, D.; Chatterjee, S. Microstructure, texture. Property relationship in thermomechanically processed ultra-low carbon microalloyed steel for pipeline application. // Materials Science and Engineering. A 587 (2013), pp. 201-208. DOI: 10.1016/j.msea.2013.08.054

[6] Wang, B.; Lian, J. Effect of microstructure on lowtemperature toughness of a low carbon $\mathrm{Nb}-\mathrm{V}-\mathrm{Ti}$ microalloyed pipeline steel. // Materials Science and Engineering. A 592 (2014), pp. 50-56. DOI: 10.1016/j.msea.2013.10.089

[7] Gutiérrez, I. Effect of microstructure on the impact toughness of Nb-microalloyed steel: Generalisation of existing relations from ferrite-pearlite to high strength microstructures. // Materials Science and Engineering. A 571 (2013), pp. 57-67. DOI: 10.1016/j.msea.2013.02.006

[8] Vodopivec, F.; Kosec, G.; Grbič, S.; Kmetič, D. On the austenite transformation during the cooling of steel Niomol $490 \mathrm{~K}$ welds. // Materiali in Tehnologije. 38 (2004), pp. 149-153.

[9] Kosec, G. Brittle fracture in the heat affected zone of steelNiomol $490 \mathrm{~K}$ welds. // Doctoral Thesis, University of Ljubljana, Ljubljana, 2007.

[10] Gojić, M. Tehnike spajanja i razdvajanja materiala. // Sveučilište u Zagrebu, Metalurški fakultet, Sisak, 2008.

[11] Shanmugam, S.; Misra, R. D. K.; Hartmann, J.; Jansto, S. G. Microstructure of high-strength niobium-containing pipeline steel. // Materials Science and Engineering. A 441 (2006), pp. 215-229. DOI: 10.1016/j.msea.2006.08.017

[12] Pisarski, H. G. HAZ Toughness Evaluation. // Proceed. of the Intern. Conf. "The Metallurgy, Welding and Qualification of Microalloyed" (HSLA) Steels Weldments, American Welding Society, 1990, pp. 351-357.

[13] Bezensek, B.; Hancock, J.W.; The toughness of laser welded joints in the ductile-brittle transition. // Engineering
Fracture Mechanics, 74 (2007), pp. 2395-2419. DOI: 10.1016/j.engfracmech.2006.11.011

[14] Sconover, T. M. Evaluation of Local Brittle Zones in HSLA-80 Weldments.// Proceed. of The Intern. Conf. "The Metallurgy, Welding and Qualification of Microalloyed" (HSLA) Steels Weldments, American Welding Society, 1990, pp. 276-305.

[15] Qianchu, L.; Xiaoxuee, D.; Yiu-Ming, M. Modelling of effect of local brittle zones on ductile tearing of weld. // Engineering Fracture Mechanics. 49, 5 (1994), pp. 741-750. DOI: 10.1016/0013-7944(94)90037-X

[16] Moltubakk, T.; Thaulow, C.; Zhang, Z. L. Application of local approach to inhomogeneous welds. Influence of crack position and strength mismatch. // Engineering Fracture Mechanics. 62, 4-5(1999), pp. 445-462. DOI: 10.1016/s00137944(98)00108-8

[17] Liu, Q.; Varga, T. The relationship between ctod, J and microstructure inhomogeneity. // Engineering Fracture Mechanics. 49 (1994) 3, pp. 435-444.

[18] Jang, J.; Lee, B.-W.; Ju, J.-B.; Kwon, D.; Kim, W. Experimental analysis of the practical LBZ effects on the brittle fracture performance of cryogenic steel HAZs with respect to crack arrest toughness wear fusion line. // Engineering Fracture Mechanics. 70, 10(2003), pp. 12451257. DOI: $10.1016 / \mathrm{S} 0013-7944(02) 00111-X$

[19] Ažman, S.; Vehovar, L.; Vojvodič Tuma, J. Development of a steel microalloyed with niobium molybdenum. // Intern. Symposium Welding 1996, Belgrade, 1996, pp. 5860.

[20] Vodopivec, F.; Šuštaršič, B., Vojvodič Tuma, J.; Kosec, G. Charpy notch toughness and hardness of reheated martensite and lower bainite. // Metalurgija. 49, 3(2010), pp. 149-154.

[21] Feng, Q.; Li, L.; Yang W.; Su, Z. Microstructures and mechanical properties of hot-rolled Nb-microalloyead TRIP steels by different thermo-mechanical processes. // Materials Science and Engineering. A 605 (2014), pp. 1421. DOI: $10.1016 /$ j.msea.2014.03.051

[22] Fan, L.; Wang, T.; Fu, Z.; Zhang, S.; Wang, Q. Effect of heat treatment on-line process temperature on the microstructure and tensile properties of a low carbon $\mathrm{Nb}$ microalloyed steel. // Materials Science and Engineering. A 607 (2014), pp. 559-568. DOI: 10.1016/j.msea.2014.04.027

[23] Trifković, B.; Budak, I.; Todorović, A.; Hodolič, J.; Puškar, T.; Jevremović. D.; Vukelić, Đ. Application of Replica Technique and SEM in Accuracy Measurement of Ceramic Crowns. // Measurement Science Review. 12 (2012) 3, pp. 90-97.

[24] Kosec, G.; Nagode, A.; Budak, I.; Antic, A.; Kosec, B.; Failure of the pinion from the drive of a cement mill. // Engineering Failure Analysis. 18, 1(2011), pp. 450-454. DOI: 10.1016/j.engfailanal.2010.09.033

[25] Lischewski, I.; Gottstein, G. Nucleation and variant selection during the $\alpha \gamma \alpha$ phase transformation in microalloyed steel. // Acta Materialia. 59, (2011), pp. 15301541. DOI: 10.1016/j.actamat.2010.11.017

[26] Shanmugam, S.; Misra, R. D. K.; Mannering, T.; Panda, D.; Jansto, S. G. Impact toughness and microstructure relationship in niobium and vanadium microalloyed steels processed with varied cooling rates to similar yield strength. // Materials Science and Engineering. A 437 (2006), pp. 436-445. DOI: 10.1016/j.msea.2006.08.007

[27] Bakkaloglu, A.; Effect of processing parameters on the microstructure and properties of $\mathrm{Nb}$ microalloyed steel. // Materials Letters. 56, (2002), pp. 200-209. DOI: 10.1016/S0167-577X(02)00440-8

[28] Zhap J.; Jiang, Z.; Soo, C. Enhancing impact fracture toughness and tensile properties of a microalloyed cast steel by hot forging and post-forging heat treatment process. // 
Materials and Design. 47, (2013), pp. 227-233. DOI: 10.1016/j.matdes.2012.11.051

[29] Najafi, H.; Rassizadehghani, J.; Norouzi, S. Mechanical properties of as-cast microalloyed steels produced via investment casting. // Materials and Design. 32, (2011), pp. 656-663. DOI: 10.1016/j.matdes.2010.08.007

\section{Authors' addresses}

Gorazd Kosec, Ass. Prof. Dr.

ACRONI d.o.o.

C. B. Kidriča 44, 4270 Jesenice, Slovenia

E-mail: gorazd.kosec@acroni.si

Jelena Vojvodič Tuma, Assoc. Prof. Dr

Institute of Energetics,

Mesarska 24, 1000 Ljubljana, Slovenia

E-mail: jelena.tuma@gmail.com

Mirko Gojić, Prof. Dr.

University of Zagreb, Faculty of Metallurgy,

Aleja narodnih heroja 3, 44103 Sisak, Croatia

E-mail: gojic@simet.hr

Aleš Nagode, Ass. Prof. Dr.

University of Ljubljana,

Faculty of Natural Sciences and Engineering,

Aškerčeva c. 12, 1000 Ljubljana, Slovenia

E-mail: ales.nagode@omm.ntf.uni-lj.si

Antun Stoić, Prof. Dr.

J. J. Strossmayer University of Osijek,

Mechanical Engineering Faculty in Slavonski Brod,

Trg Ivane Brlić Mažuranić 2, 35000 Slavonski Brod, Croatia

E-mail: astoic@sfsb.hr

Ivan Samardžić, Prof. Dr.

J. J. Strossmayer University of Osijek,

Mechanical Engineering Faculty in Slavonski Brod,

Trg Ivane Brlić Mažuranić 2, 35000 Slavonski Brod, Croatia

E-mail: isamar@sfsb.hr

Borut Kosec, Prof. Dr.

University of Ljubljana,

Faculty of Natural Sciences and Engineering,

Aškerčeva c. 12, 1000 Ljubljana, Slovenia

E-mail: borut.kosec@omm.ntf.uni-lj.si 